\title{
Clinical Case: Treatment of a Giant Cells Tumor of the Proximal Femur in a Disadvantaged Area
}

\author{
M. Sawadogo ${ }^{*}$, S. Ouedraogo' ${ }^{1}$ A. Korsaga ${ }^{2}$, S. Tinto ${ }^{2}$, A. J. I. Ouedraogo ${ }^{2}$, H. Kafando², \\ S. Ouedraogo', M. Tall', S. C. Da ${ }^{2}$ \\ ${ }^{1}$ Ouahigouya Regional University Hospital Center, Ouahigouya, Burkina Faso \\ ${ }^{2}$ Yalgado Ouedraogo University Hospital, Ouagadougou, Burkina Faso \\ Email: *smamoudou@hotmail.com, ouedraogo_salam@hotmail.com, korsalexs@yahoo.fr, drstinto@yahoo.fr, \\ anatoleji2001@yahoo.fr, hkafando@gmail.com, souleymane.oued@yahoo.fr, mohatall@yahoo.fr, songahirda@yahoo.fr
}

How to cite this paper: Sawadogo, M., Ouedraogo, S., Korsaga, A., Tinto, S., Ouedraogo, A.J.I., Kafando, H., Ouedraogo, S., Tall, M. and Da, S.C. (2017) Clinical Case: Treatment of a Giant Cells Tumor of the Proximal Femur in a Disadvantaged Area. Open Journal of Orthopedics, 7, 362-368. https://doi.org/10.4236/ojo.2017.711037

Received: September 18, 2017

Accepted: November 6, 2017

Published: November 9, 2017

Copyright (C) 2017 by authors and Scientific Research Publishing Inc. This work is licensed under the Creative Commons Attribution International License (CC BY 4.0).

http://creativecommons.org/licenses/by/4.0/

\begin{abstract}
There have been not many reports on the result of intralesional excision for giant cell tumors (GCTs) of the great trochanter and femoral neck because of its rarity. The authors present the case of a 35-year-old female patient managed with intralesional curettage and filling the defect with autologous bone graft from iliac crest. An appoint of three doses of Denosumab was done postoperatively. The article discusses the clinical aspects and surgical treatment, and the benefits of Denosumab. This report aimed to demonstrate the possibility to perform curetage for giant cell tumor of the hip even the recommandation for this location is wide resection and endoprothesis fixation.
\end{abstract}

\section{Keywords}

Giant Cell Tumor, Femoral Neck, Great Trochanter, Curettage, Denosumab

\section{Introduction}

Giant cell tumors (GCT) are relatively rare (5\% to $10 \%$ of bone tumors). They are benign in $90 \%$ of cases and more often sit on the limbs (90\%) with an almost constant epiphyso-metaphyseal localization: knee (60\%), proximal end of the humerus (15\%), distal ends of the radius (10\%) \%) or tibia (10\%). These are tumors of young adults (75\% of cases between 20 and 40 years) [1]. Curettage and filling the osseous defect is the reference treatment for uncomplicated cases, but is followed by local recurrences in $20 \%$ to $40 \%$ of cases [2] [3] [4]. Moreover, in terms of localization to the proximal femur, few results are reported due to its rarity. There are only a few "case reports" and short series [5] [6] [7] [8], all of which suggest that resection and prosthetic reconstruction is the reference 
treatment in this location. We report a case of a 35-year-old patient for whom we opted for conservative treatment because of our unfavorable socio-economic context and young age.

\section{Observation}

Mrs. SM, a 35-year-old patient consulted in the department for pain and dodge lameness of the left hip evolving for six months around. There was no notion of trauma. There was no specific pathological history. On examination, there was a pain awakened to the palpation supported by the greater trochanter and to the mobilization of the hip. The mobility of the joint was normal. The general condition was well preserved and the biological balance showed no abnormality. The standard X-ray of the frontal pelvis and the profile hip showed a circumscribed osteolytic image of the greater trochanter and of the femoral neck (Figure 1).

CT showed a tissue osteolysis of $49 \times 40 \times 39 \mathrm{~mm}$ of the neck and the greater trochanter with the upper cortex almost broken without periosteal reaction or medullary perilesional condensation. The surrounding soft tissues were free of abnormalities (Figure 2).

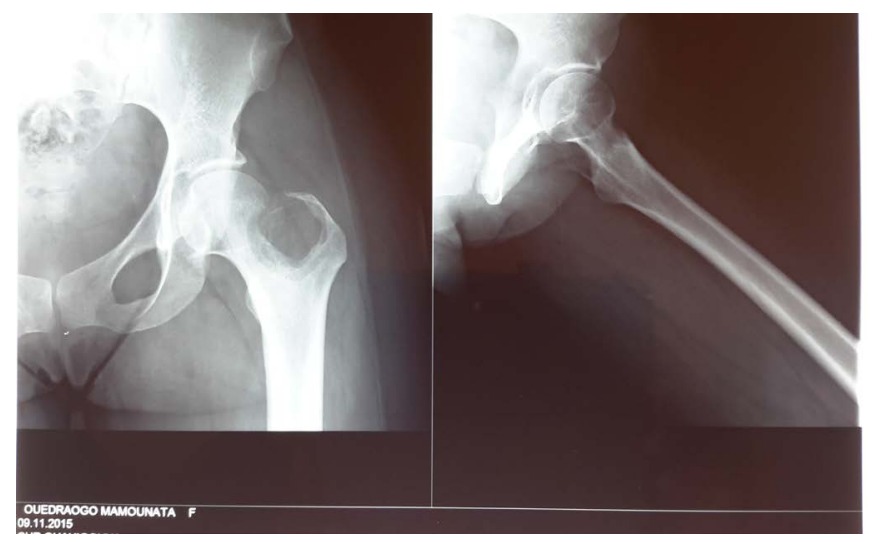

Figure 1. X-ray of the pelvis showing the tumor.

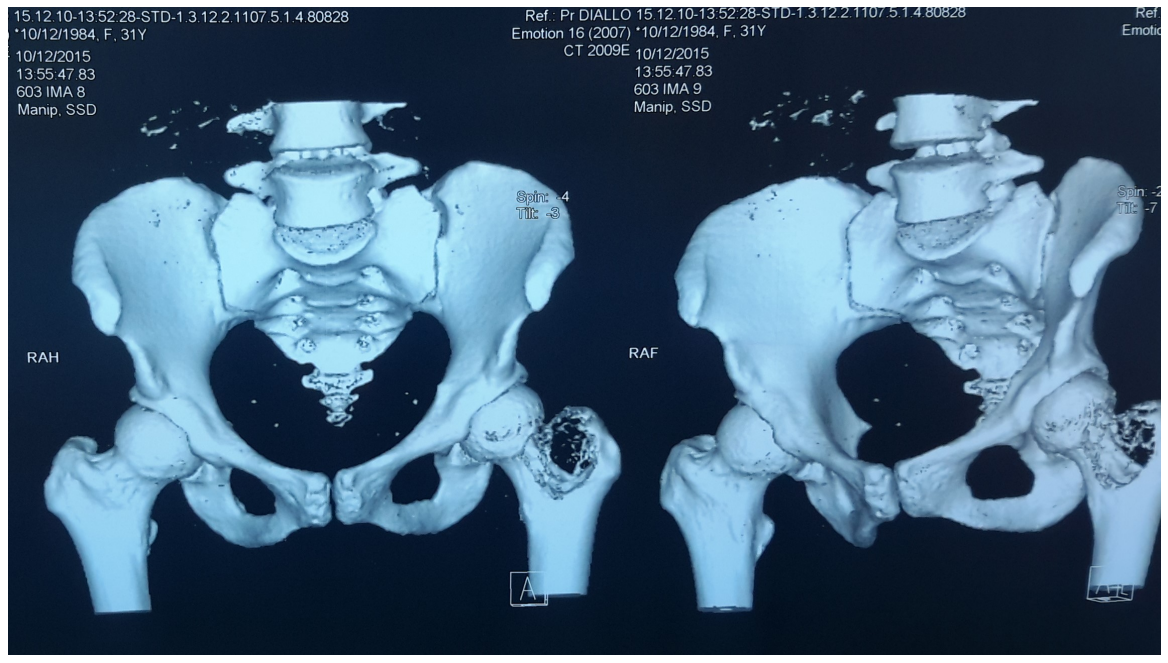

Figure 2. CT showing the osteolysis and soft tissues free of abnormalities. 


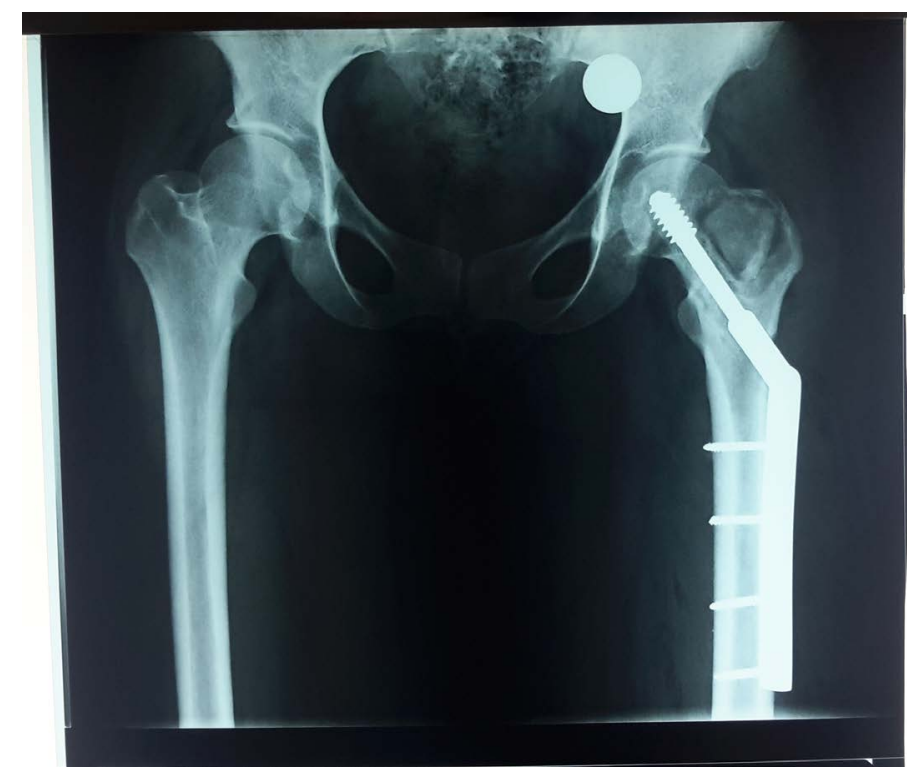

Figure 3. X-ray after curettage, filling by a graft of the iliac crest and stabilization by DHS.

A biopsy was performed and the diagnosis of GCT was made and classified as stage II of Enneking. We proceeded, by a Watson-Jones approch, to a careful curettage with cauterization of the bone walls with the electric scalpel. The residual cavity was filled by a tri cortical graft of the iliac crest and a stabilization by dynamic hip screw was made (Figure 3 ).

The histological study confirmed the diagnosis of GCT by showing a bone tissue sited with a cell proliferation background made up of mononuclear cells within which were dispersed giant osteoclastic type cells with numerous nuclei and connective tissue supporting seat of areas of necrosis, haemorrhage and osteogenesis reaction. There was no character of malignity.

The patient was released on the third postoperative day with ambulation landfill by two crutches for six weeks, then relieved by support contralateral crutch for another six weeks. In the $10^{\text {th }}$ postoperative day, fluctuating collection has fistulized below the surgical scar and let flow a whitish, thick liquid whose culture came back negative. Drying and scarring occurred rapidly after a few dressings. Complementary treatment with Denosumab $120 \mathrm{mg}$ was administered as a subcutaneous injection per month for 3 months.

At six months postoperative, the patient was asymptomatic. A good fusion of the bone graft was noted (Figure 4).

At two years of age, the patient was still asymptomatic and the radiographs showed no recurrence (Figure 5).

\section{Discussion}

The treatment of GCT is primarily surgical. These are tumors that can be locally aggressive and sometimes give distant metastases although they are considered histologically as benign. The goal of the treatment is to eliminate the entire 


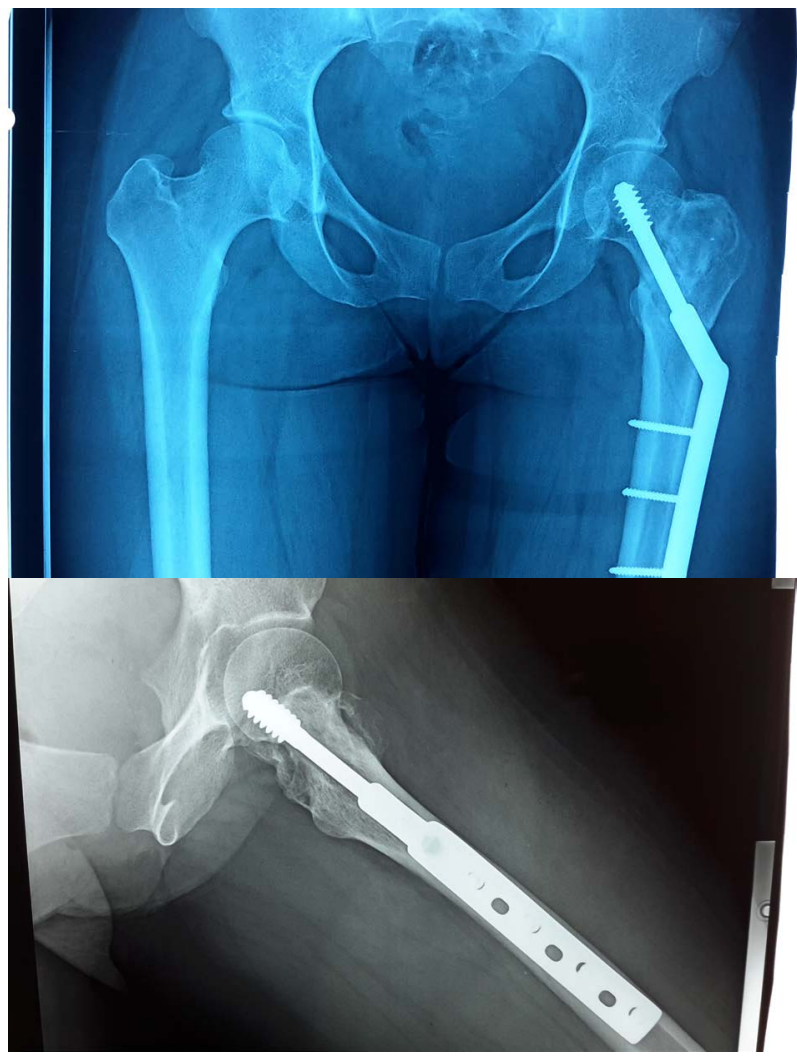

Figure 4. X-ray at six months postoperative showing good fusion of the bone graft.

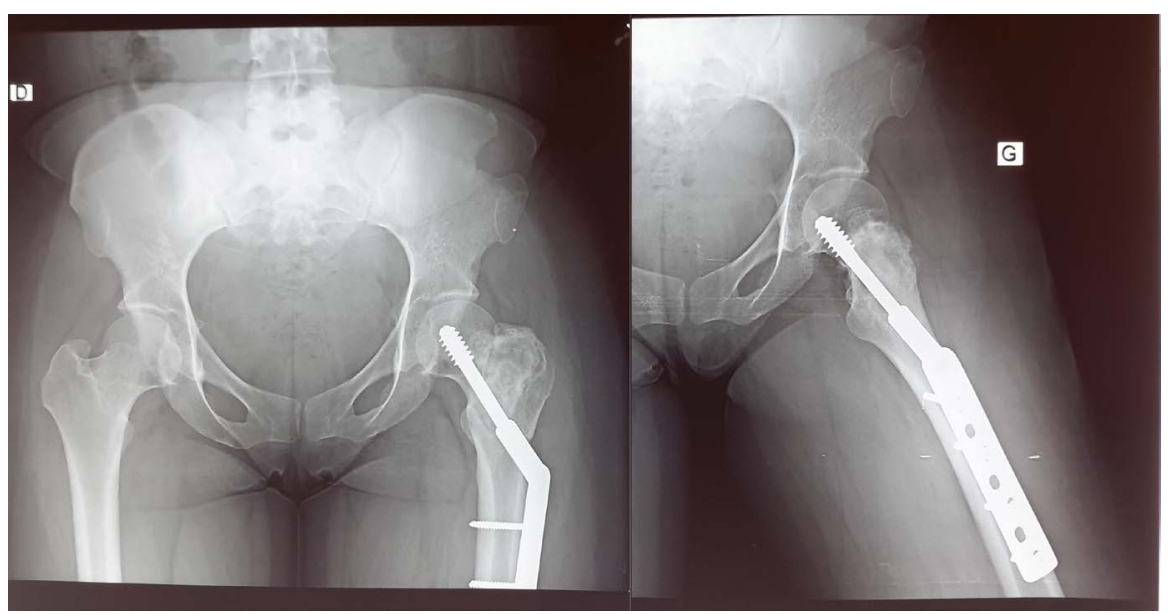

Figure 5. X-ray at two years postoperative showing norecurrence.

tumor to prevent recurrence. For this, the therapeutic options are curettage with most often adjuvant local treatment and wide resection with reconstruction [9]. The curettage must be careful to eliminate the whole tumor. Adjuvant measurements may be associated with this: electric cautery of the walls of the tumor cavity, liquid nitrogen, distilled water, phenol, embolization, intra-tumor calcitonin injection, radiotherapy or chemotherapy [10] [11] [12]. The filling of the defect is ensured by bone grafts or acrylic cement. The resection, in turn, must be of 
the carcinological type and aims to prevent any recurrence. But it has sometimes important functional consequences [13] [14]. Moreover most surgeons are reluctant to perform a prosthetic reconstruction in a young adult. Despite these reservations, some authors advocate this method in the proximal femur [15].

Whatever the method used, recurrences are frequent, occurring between a few months and five years, in proportions of $20 \%$ to $40 \%$ according to the series [16] [17] [18] [19]. In 15\% of cases, it is malignant degeneration [20] [21] [22]. The recurrence factors explored in the literature are age, sex, tumor site, histological grade, pathological fracture and type of surgery. For most authors there is no statistically significant relationship between these factors and the reccurence. [22] [23]. As for the type of surgery (curettage or resection), only the functional result differs and is better in the case of conservative treatment [24]. The majority of authors therefore consider curettage to be the first-line method of treating most cases of GCT, even in the event of recurrence [3] [4] [19] [22]. More recently, Denosumab has demonstrated its effectiveness [25] [26] [27] [28] [29]. In the Norwegian protocol [26] the administration of Denosumab in postoperative care was performed by subcutaneous injection every 4 weeks for a period of six months.

The location of GCT at the proximal end of the femur is quite rare. In our precarious situation, total hip arthroplasty remains a challenge, especially if it is a reconstruction with special prostheses. So we had only the option of curettagefill that we realized. To strengthen this treatment, we have added Denosumab. But given the high cost of the product we administered only 3 injections at 1 month intervals. At 2 years postoperative, we have not yet observed a recurrence. This seems to testify to the efficacy of Denosumab, even if administered for a limited time. However, regular monitoring should be continued for a few more years because recurrences at fifteen or even twenty years have been described [20] [30].

\section{Conclusions}

The treatment of the circumscribed GCT is resolutely surgical and the curettagefilling is the method of choice. The appearance of Denosumab has improved the prognosis. The result we have reached suggests at least for the moment that the duration of administration may be shortened, in particular when financial accessibility is limited.

The authors declare that they have no competing interests.

The authors state that the patient has freely consented to the publication of the case and that the signed consent is available.

\section{References}

[1] Tomeno, B. (2004) Management of a Giant Cell Tumor. Maîtrise Orthopédique, $\mathrm{N}^{\circ} 136$, August.

[2] Becker, W.T., Dohle, J., Bernd, L., Braun, A., Cserhati, M., Enderle, A., Hovy, L., Matejovsky, Z., Szendroi, M., Trieb, K. and Tunn, P.U. (2008) Local Recurrence of 
Giant Cell Tumor of Bone after Intralesional Treatment with and without Adjuvant Therapy. The Journal of Bone and Joint Surgery-American, 90, 1060-1067. https://doi.org/10.2106/JBJS.D.02771

[3] Blackley, H.R., Wunder, J.S., Davis, A.M., White, L.M., Kandel, R. and Bell, R.S. (1999) Treatment of Giant-Cell Tumors of Long Bones with Curettage and BoneGrafting. The Journal of Bone and Joint Surgery-American, 81, 811-820. https://doi.org/10.2106/00004623-199906000-00008

[4] Zhen, W., Yaotian, H., Songjian, L., Ge, L. and Qingliang, W. (2004) Giant Cell Tumour of Bone: The Long-Term Results of Treatment by Curettage and Bone Graft. The Journal of Bone and Joint Surgery, 86, 212-216. https://doi.org/10.1302/0301-620X.86B2.14362

[5] Sim, E. and Lang, S. (1997) Joint Salvaging Surgery for an Extensive Giant Cell Tumor of the Proximal Femur Complicated by a Transcervical Fracture. Archives of Orthopaedic and Trauma Surgery, 116, 431-434. https://doi.org/10.1007/BF00434008

[6] Sakayama, K., Sugawara, Y., Kidani, T., Miyawaki, J., Fujibuchi, T., Kamei, S., Aizawa, J. and Yamamoto, H. (2007) Diagnostic and Therapeutic Problems of Giant Cell Tumor in the Proximal Femur. Archives of Orthopaedic and Trauma Surgery, 127, 867-872. https://doi.org/10.1007/s00402-007-0419-3

[7] Tibrewal, S.B. (1986) Treatment of Giant Cell Tumour of the Femoral Head and Neck. Journal of the Royal Society of Medicine, 79, 401-404. https://doi.org/10.1177/014107688607900707

[8] Wai, E.K., Davis, A.M., GriYn, A., Bell, R.S. and Wunder, J.S. (2001) Pathologic Fractures of the Proximal Femur Secondary to Benign Bone Tumors. Clinical Orthopaedics and Related Research, 393, 279-286. https://doi.org/10.1097/00003086-200112000-00032

[9] Camargo, O.P., Croci, A.T., Oliveira, C.R.G., Baptista, A.M., Caiero, M.T. and Giannotti, M.A. (2001) Tumor de células gigantes evoluc ão histórica do seu diagnóstico e tratamento junto ao Instituto de Ortopedia e Traumatologia da FMUSP. Acta Ortopedica Brasileira, 9, 46-52. https://doi.org/10.1590/S1413-78522001000400006

[10] Kivioja, A.H., Blomqvist, C., Hietaniemi, K., Trovik, C., Walloe, A., Bauer, H.C., et al. (2008) Cement Is Recommended in Intralesional Surgery of Giant Cell Tumors: A Scandinavian Sarcoma Group Study of 294 Patients Followed for a Median Time of 5 Years. Acta Orthopaedica, 79, 86-93. https://doi.org/10.1080/17453670710014815

[11] Mendenhall, W.M., Zlotecki, R.A., Scarborough, M.T., Gibbs, C.P. and Mendenhall, N.P. (2006) Giant Cell Tumor of Bone. American Journal of Clinical Oncology, 29, 96-99. https://doi.org/10.1097/01.coc.0000195089.11620.b7

[12] Abdelkafi, M.M., Medbed, T.K., Siala, A. and Kassab, M. T. (1992) Traitement Non Invasif des tumeurs à cellules géantes des os: A propos de 10 cas. [Non-Invasive Treatment of Giant Cell Tumors of Bones: About 10 Cases.] Encyclopédie médicochirurgicale, No. 5, 21-26.

[13] Filho, R.J.G., Korukian, M., Ishirara, H.I., Miceno Filho, N.M., Figueiredo, M.T.B. and Seixas, M.T. (1993) É a curetagem um método eficiente no tratamento dos tumores ósseos? Revista Brasileira de Ortopedia, 28, 813-816.

[14] Oda, Y., Miura, H., Tsuneyoshi, M. and Iwamoto, Y. (1998) Giant Cell Tumor of Bone: Oncological and Functional Results of Long-Term Follow-Up. Japanese Journal of Clinical Oncology, 28, 323-328. https://doi.org/10.1093/jjco/28.5.323

[15] Silva, P., do Amaral, R.A., de Oliveira, L.A., de Moraes, F.B. and Chaibe, E.D. (2016) 
Giant Cell Tumor of the Femoral Neck: Case Report. Revista Brasileira de Ortopedia, 51, 739-743.

[16] Xu, H. and Niu, X. (2014) Analysis of the Risk Factors for Local Recurrence of Giant Cell Tumor of Long Bone. Chinese Journal of Oncology, 36, 465-468.

[17] Arbeitsgemeinschaft, K., Becker, W.T., Dohle, J., Bernd, L., Braun, A., Cserhati, M., et al. (2008) Local Recurrence of Giant Cell Tumor of Bone after Intralesional Treatment with and without Adjuvant Therapy. The Journal of Bone and Joint Surgery. American Volume, 90, 1060-1067. https://doi.org/10.2106/JBJS.D.02771

[18] Guo, W., Sun, X., Zang, J. and Qu, H. (2012) Intralesional Excision versus Wide Resection for Giant Cell Tumor Involving the Acetabulum: Which Is Better? Clinical Orthopaedics and Related Research, 470, 1213-1220.

[19] Rastogi, S., Prashanth, I., Khan, S.A., Trikha, V. and Mittal, R. (2007) Giant Cell Tumor of Bone: Is Curettage the Answer? Indian Journal of Orthopaedics, 41, 109-114.

[20] Li, J., Zhu, Y. and Wei, Y. (2014) Fibrosarcoma Development 15 Years after Curettage and Bone Grafting of Giant Cell Tumor of Bone Orthopedics. Orthopedics, 37, 512-516.

[21] Scully, S.P., Mott, M.P., Temple, H.J., O’Keefe, M.J., O’Donnell, R.J. and Mankin, H.J. (1994) Late Recurrence of Giant Cell Tumor of Bone. A Report of Four Cases. The Journal of Bone and Joint Surgery. American Volume,76A,1231-1233.

[22] Siddiqui, M.A., Seng, C. and Tan, M.H. (2014) Risk Factors for Recurrence of Giant Cell Tumours of Bone. Journal of Orthopaedic Surgery, 22, 108-110. https://doi.org/10.1177/230949901402200127

[23] Yacob, O., Umer, M., Gul, M. and Qadir, I. (2016) Segmental Excision versus Intralesional Curettage with Adjuvant Therapy for Giant Cell Tumour of Bone. Journal of Orthopaedic Surgery, 24, 8. https://doi.org/10.1177/230949901602400120

[24] Cho, H.S., Park, I.-H., Han, I., Kang, S.C. and Kim, H.-S. (2010) Giant Cell Tumor of the Femoral Head and Neck: Result of Intralesional Curettage. Archives of Orthopaedic and Trauma Surgery, 130, 1329-1333.

[25] Palmerini, E., et al. (2017) Denosumab in Advanced/Unresectable Giant-Cell Tumour. European Journal of Cancer, 76, 118e124.

[26] Boye, K., Jebsen, N.L., Zaikova, O., Knobel, H., Løndalen, A.M., Trovik, C.S., Monge, O.R. and Hall, K.S. (2017) Denosumab in Patients with Giant-Cell Tumor of Bone in Norway: Results from a Nationwide Cohort. Acta Oncologica, 56, 479-483.

[27] Thornley, P., Habib, A., Bozzo, A., Evaniew, N. and Ghert, M. (2017) The Role of Denosumab in the Modern Treatment of Giant Cell Tumor of Bone. JBJS Reviews, $5, \mathrm{e} 4$.

[28] Gaston, C.L., Puls, F. and Grimer, R.J. (2014) The Dilemma of Denosumab: Salvage of a Femoral Head Giant Cell Tumour. International Journal of Surgery Case Reports, 5, 783-786.

[29] Menon, P.D., Krishnakumar, R. and Jojo, A. (2016) Radiological and Histopathological Outcome of Giant Cell Tumor of Femur with Denosumab Treatment: A Case Report. Journal of Clinical and Diagnostic Research, 10, RD01-RD03. https://doi.org/10.7860/JCDR/2016/22172.9070

[30] Brousse, C.H., Paszkowskia, A., Moisson, P., Epardeau, B., Baumelou, E. and Mignot, L. (1995) Tumeur à cellules géantes: Forme récidivante puis transformation maligne. [Giant Cell Tumor: Recurrent form Followed by Malignant Transformation.] Rachis, 8, 45-49. 